УДК 618.3-06: 616.24-002.5]: 612.013

DOI

\author{
๑С. П. Польова, О. В. Романюк
}

Вінницький національний медичний університет ілені М. І. Пирогова

\title{
ІМУНО-ГОРМОНАЛЬНИЙ ГОМЕОСТАЗ ПРИ ПОРУШЕННІ МЕНСТРУАЛЬНОГО ЦИКЛУ У ЖІНОК, ЩО ХВОРІЮТЬ НА ТУБЕРКУЛЬОЗ
}

ІМУНО-ГОРМОНАЛЬНИЙ ГОМЕОСТАЗ ПРИ ПОРУШЕННІ МЕНСТРУАЛЬНОГО ЦИКЛУ У ЖІНОК, ЩО ХВОРІЮТЬ НА ТУБЕРКУЛЬОЗ. У статті наведені дані дослідження показників неспецифічного та специфічного імунного захисту в пацієнток із порушеннями менструального циклу, що хворіють на туберкульоз (ТБ) легень. Показано, що менструальний цикл у даної когорти жінок зазнає суттєвих порушень завдяки змінам неспецифічної системи протиінфекційного захисту та клітинній ланці системи імунітету. Встановлена роль гуморальної ланки системного імунітету у комплексі порушень менструальної фрункції у пацієнток, що хворіють на туберкульоз.

ИММУННО-ГОРМОНАЛЬНЫЙ ГОМЕОСТАЗ ПРИ НАРУШЕНИИ МЕНСТРУАЛЬНОГО ЦИКЛА У ЖЕНЩИН, БОЛЕЮЩИХ ТУБЕРКУЛЕЗОМ. В статье приведены данные исследования показателей неспецисической и специфической иммунной защиты у пациенток с нарушениями менструального цикла, болеющих туберкулезом легких. Показано, что менструальный цикл у данной категории женщин испытывает существенные изменения благодаря показателям неспецисической системы противоинфекционной защиты и клеточному звену системы иммунитета. Установлена роль гуморального звена системного иммунитета в комплексе нарушений менструальной функции у пациенток, болеющих туберкулезом.

IMMUNO-HORMONAL HEMOSTASIS UNDER MENSTRUAL CYCLE DISORDERS IN WOMEN WITH TUBERCULOSIS. The article presents research data of indicators of non-specific and specific immune resistance in patients with menstrual cycle irregularities $(\mathrm{MCl})$, with pulmonary tuberculosis. It is shown that the menstrual cycle $(\mathrm{MC})$ in this cohort of women undergoes significant changes due to violations of non-specific immune defense system and a cellular link of the immune system, which provides regulation of phagocytosis and lysis of Mycobacterium tuberculosis and form the anti-tuberculosis immunity. Study of systemic humoral immunity in women with TB showed significant role of specific humoral immunity in the $\mathrm{MCl}$ complex in women with TB because antibodies to mycobacterial antigens circulate in the blood under the presence of any form of tuberculosis.

Ключові слова: менструальний цикл, туберкульоз, лімфоцити, імунітет, діагностика.

Ключевые слова: менструальный цикл, туберкулез, лимсоциты, иммунитет, диагностика.

Key words: menstrual cycle, tuberculosis, lymphocytes, immunity diagnostics.

ВСТУП. У комплексному лікуванні вперше діагностованого туберкульозу (ВДТБ) із сучасних позицій одночасно застосовують декілька препаратів, які негативно впливають на гормональний і стероїдний обмін, не сприяють гормональному гомеостазу та стану репродуктивної системи у жінок [4, 5]. Порушення менструального циклу (ПМЦ) у даного контингенту жінок переважно пов'язані 3 інтоксикаційною дією хіміопрепаратів на гіпоталамогіпофрізарно-яєчникову систему, що зумовлює виникнення низки гінекологічних захворювань $[1,4,5]$. За умов туберкульозу ПМЦ трапляється у 36,8 \% осіб [6]. Застосування хіміотерапії проти ТБ у жінок фрертильного віку привело до необхідності визначити вплив туберкульозного ураження на менструальну функцію, репродуктивні органи, реактивність організму, стан гормональної та ендокринної системи жінок [2, 3, 7, 9].

Механізмом захисту організму за умов туберкульозу $€$ Т-ланка імунної системи, яка здійснює регуляцію фрагоцитозу і лізису мікобактерій та фрормує протитуберкульозний імунітет. Роль специфічної гуморальної ланки імунітету у комплексі захисних реакцій у жінок, хворих на ТБ, є також суттєвою, проте висвітлена у літературі недостатньо [5, 6, 8]. Антитіла до мікобактеріальних антигенів циркулюють у крові за наявності будь-якої форми туберкульозу, проте імунна відповідь на антитіла до ТБ індивідуальна та складна і залежить від багатьох чинників.
Мета роботи - визначити механізми неспецисічного та специфічного імунного протиінфекційного захисту при порушенні менструального циклу у жінок, що хворіють на туберкульоз легень.

МАТЕРІАЛИ ТА МЕТОДИ. Проведено обстеження 48 пацієнток репродуктивного віку, що хворіють на ТБ легень (основна група), 30 здорових жінок (контрольна група). Середній вік склав $29,7 \pm 3,5$ роки. Репродуктивну функцію пацієнток вивчали такими загальноприйнятими в гінекології методами діагностики, як: анамнезу захворювання, клінічно-лабораторні методи, гормональне та інструментальне обстеження.

Цільну кров досліджували на гематологічному аналізаторі «Ce1trak-11» фрірми «Baer» (Австрія). Фагоцитарну активність нейтрофрілів крові досліджували за визначенням фрагоцитарного числа та фрагоцитарної активності у відсотках фрагоцитуючих клітин. Основні субпопуляції Т- і В-лімсроцитів проводили у реакції непрямої поверхневої імунофлуоресценції з моноклональними антитілами (фірми «Сорбент-лТД», Москва). Рівень імуноглобулінів основних класів (IgM, IgG, IgA) у сироватці крові визначали прямим методом радіальної імунодифузії в агарі за Манчіні.

РЕЗУЛЬТАТИ ДОСЛІДЖЕННЯ ТА ЇХ ОБГОВОРЕННЯ. Аналіз акушерсько-гінекологічного анамнезу показав, що в $11(22,9 \%)$ пацієнток основної групи мало місце пізнє менархе. Порушення репродуктивної фрункції проявляли- 
ся альгодисменореєю - у 13 (27,0 \%) осіб, дисменореєю - у 7 (14,5 \%) жінок; у 3 (6,2 \%) - гіперполіменореєю, опсоменореєю - у 2 (8,6 \%) та аменореєю - в однієї (2,0 \%) пацієнтки. Дослідження гормональної функції показали, що в цілому за наявності ТБ легень ПМЦ більшою мірою визначалися гіперестрогенемією. Рівень фролікулостимулювального гормону (ФСГ) жінок основної групи сягав до

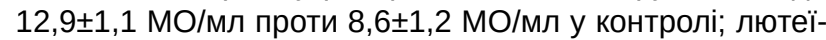

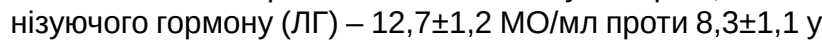

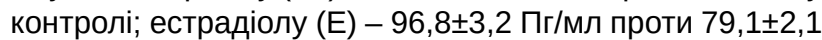
у контролі і прогестерону (Пг) - 19,5 $\pm 3,4$ нмоль/л проти $17,7 \pm 2,7$ нмоль/л у контролі.

У пацієнток основної групи встановлені суттєві зміни показників неспецифічної ефекторної системи протиінфрекційного захисту: III ступінь імунних порушень виявлено у $50 \%$ жінок основної групи, II - у $37 \%$, і III - у 12,5\% осіб. Серед здорових жінок у 5 (16,6 \%) спостерігали незначне зростання (на 17,4 \%) імунологічного коефріцієнта, що, можливо, є наслідком гормональних змін у динаміці МЦ, проте імунні зрушення у даної категорії пацієнток не виходили за межі І ступеня.

Результати визначення неспецифрічного протиінсекційного захисту за наявності ВДТБ легень у жінок репродуктивного віку показали суттєві порушення імунного гомеостазу: фрагоцитарна активність поліморфнноядерних лейкоцитів знижувалася на 16,4 \% при зростанні їх бактерицидної активності на 57,9 \%. Потенційна здатність до бактерицидної активності фрагоцитувальних клітин у даної когорти жінок знижувалася на 40,0 \%, що призводило до незавершеності фрагоцитозу. Показник фагоцитарного резерву знижувався у 3,42 раза, а імунологічний коефріцієнт зростав на 85,9 \%. При цьому відносна кількість 0-лімфроцитів (кілінгова фрункція 0-лімфоцитів), їх аналітичний індекс і вміст катіонних білків суттєво не змінювалися.

Враховуючи, що за умов ТБ переважно фрормується клітинна імунна відповідь, наступним етапом було вивчення показників клітинної ланки системного імунітету при ПМЦ у жінок, хворих на ТБ.
У частини жінок контрольної групи ступінь імунних порушень (І ступінь) характеризувався неістотними змінами і показники клітинної ланки системного імунітету знаходилися у межах показників здорових жінок. Вказані відхилення розглядали як адекватну реакцію системи імунітету на гормональний гомеостаз у динаміці МЦ.

У пацієнток основної групи встановлена тенденція до зниження відносної кількості загальних Т-лімфоцитів (CD ${ }^{3+}$-клітин) на 10,7\% (p<0,05), проліферативної здатності на неспецифічний стимулятор (ФГА) - на $16,5 \%(p<0,05)$ та $\mathrm{CD}^{4+}$-лімфоцитів - на 33,4\%. При цьому зростала відносна кількість $\mathrm{CD}^{8+}$-лімфроцитів на 19,2 \%, проліферативна здатність Т-лімфоцитів на ППД-у 3,19 раза, лейкоТ-клітинний індекс - на 33,3 \%, що підтверджує десріцит загального пулу Т-лімфоцитів, та імунологічний коефріцієнт - на 17,4 \%. Все це є свідченням фрормування набутого імунодесріцитного стану за клітинним типом зі зниженням на 62,6 \% імунорегуляторного індексу (табл. 1).

Із зменшенням абсолютної та відносної кількості сумарних лімфоцитів різко знижувався вміст загальної популяції Т-лімфоцитів $\left(\mathrm{CD}^{3+}\right)$, i, особливо, субпопуляцій $\mathrm{CD}^{4+}$-лімфоцитів (Т-хелперів/індукторів) при зростанні вмісту $\mathrm{CD}^{8+}$-лімфроцитів (Т-цитотоксичні) і популяцій В-лімсоцитів $\left(\mathrm{CD}^{20+}\right)$. Перерозподіл чисельного співідношення Т-хелперів і Т-цитотоксичних лімфоцитів (IPI) призвів до зниження майже у два рази показника $\mathrm{CD}^{4+} / \mathrm{CD}^{8+}$ у жінок, хворих на ТБ, який наближався до $1(1,34+0,05)$, що свідчить про напружену роботу імунної системи та фрормування набутого імунодефріцитного стану, надмірне перевантаження імунної системи жінок, хворих на ТБ, що суттєво відображається на ПМЦ.

Дослідження гуморальної ланки системного імунітету у жінок, хворих на ТБ, показали (табл. 2), що у даної когорти пацієнток встановлені більш суттєві порушення: I, II та III ступені імунних порушень встановлені однаково часто серед пацієнток основної групи - по 33,3 \%. При цьому відносна кількість В-лімфроцитів ( $\mathrm{CD}^{20+}$-клітин) зростала на 46,5 \%, проте загальна фрункціональна здатність знижувалася на 5,6 \% щодо синтезу та продукції імуногло-

Таблиця 1. Показники клітинної ланки імунітету у жінок, хворих на туберкульоз легень

\begin{tabular}{|c|c|c|c|c|c|c|}
\hline \multirow[b]{2}{*}{ Показники } & \multirow{2}{*}{$\begin{array}{l}\text { Одиниці } \\
\text { виміру }\end{array}$} & \multicolumn{4}{|c|}{ Жінки досліджуваних груп } & \multirow[b]{2}{*}{$\mathrm{P}$} \\
\hline & & $\begin{array}{c}\text { основна група }(n=48) \\
(M \pm m)\end{array}$ & $\mathrm{CI \Pi}$ & $\begin{array}{c}\text { контрольна група }(\mathrm{n}=30) \\
(\mathrm{M} \pm \mathrm{m})\end{array}$ & СІП & \\
\hline $\begin{array}{l}\text { Загальний пул Т-лімсроцитів } \\
\text { (CD3+) }\end{array}$ & $\%$ & $62,80 \pm 2,41$ & 1 & $73,90 \pm 2,89$ & 1 & $<0,01$ \\
\hline \multicolumn{7}{|l|}{ Субпопуляції Т-лімфоцитів: } \\
\hline$-\quad \mathrm{CD}^{4+}$ & $\%$ & $36,40 \pm 1,61$ & 1 & $46,10 \pm 1,99$ & I & $>0,05$ \\
\hline$-\quad C D^{8+}$ & $\%$ & $26,30 \pm 1,24$ & 1 & $21,80 \pm 1,17$ & 1 & $>0,05$ \\
\hline $\mathrm{IPI}\left(\mathrm{CD}^{4+} / \mathrm{CD}^{8+}\right)$ & од. & $1,38 \pm 0,05$ & II & $2,10 \pm 0,08$ & $\mathrm{I}$ & $<0,05$ \\
\hline Лейко-Т-клітинний індекс & од. & $0,13 \pm 0,02$ & 1 & $0,10 \pm 0,02$ & $\mathrm{I}$ & $>0,05$ \\
\hline \multicolumn{7}{|l|}{ РБТЛ: } \\
\hline - $\quad 3$ ФГА & $\%$ & $51,73 \pm 0,84$ & 1 & $61,40 \pm 1,52$ & I & $<0,01$ \\
\hline - & $\%$ & $3,92 \pm 0,37$ & III & $1,32 \pm 0,16$ & 1 & $<0,01$ \\
\hline Імунологічний коесріцієнт & $\%$ & $26,75 \pm 1,03$ & II & $16,91 \pm 0,97$ & $\mathrm{I}$ & $<0,01$ \\
\hline
\end{tabular}

Примітки:

1. СІП - ступінь імунних порушень.

2. P - порівняння показників жінок основної групи з показниками контрольної групи. 
Таблиця 2. Показники гуморальної ланки системного імунітету в жінок, хворих на туберкульоз легень

\begin{tabular}{|c|c|c|c|c|c|c|}
\hline \multirow[b]{2}{*}{ Показники } & \multirow[b]{2}{*}{$\begin{array}{l}\text { Одиниці } \\
\text { виміру }\end{array}$} & \multicolumn{2}{|c|}{ Основна група $(\mathrm{n}=48)$} & \multicolumn{2}{|c|}{ Контрольна група (n=30) } & \multirow[b]{2}{*}{$\mathrm{P}$} \\
\hline & & $\begin{array}{c}\text { пацієнтки, хворі на } \\
\text { туберкульоз легень } \\
(\mathrm{M} \pm \mathrm{m})\end{array}$ & $\mathrm{CI}$ & $\begin{array}{c}\text { здорові } \\
\text { жінки }(\mathrm{n}=32) \\
(\mathrm{M} \pm \mathrm{m})\end{array}$ & $\mathrm{CI}$ & \\
\hline В-лімфроцити $\left(\mathrm{CD}^{20+}\right)$ & $\%$ & $18,52 \pm 1,23$ & II & $12,64 \pm 1,17$ & $\mathrm{I}$ & $<0,01$ \\
\hline Лейко-В-клітинний індекс & од. & $0,42 \pm 0,05$ & $\mathrm{I}$ & $0,53 \pm 0,05$ & $\mathrm{I}$ & $<0,05$ \\
\hline $\begin{array}{l}\text { Концентрація } \\
\text { імуноглобулінів }\end{array}$ & г/л & $15,44 \pm 0,37$ & I & $16,31 \pm 0,46$ & I & $<0,05$ \\
\hline $\lg \mathrm{M}$ & г/л & $2,77 \pm 0,18$ & III & $1,32 \pm 0,17$ & II & $<0,05$ \\
\hline $\lg G$ & г/л & $10,13 \pm 0,63$ & II & $13,50 \pm 0,88$ & I & $<0,05$ \\
\hline $\lg A$ & г/л & $2,54 \pm 029$ & III & $1,49 \pm 0,34$ & I & $<0,05$ \\
\hline
\end{tabular}

Примітки:

1. СІП - ступінь імунних порушень.

2. P - порівняння показників жінок основної групи з показниками здорових жінок.

булінів основних класів. Негативним виявилося зниження рівня IgG на 33,2 \%, які виконують основну захисну роль у протиінфекційному захисті, зростала концентрація IgM на $53,8 \%$ та IgA на $81,4 \%$.

У здорових жінок зменшилася відносна кількість В-лімфоцитів (CD ${ }^{20+}$ клітин) на 17,0\%, спостерігалася тенденція до зростання лейкоцитарного В-клітинного індексу та зниження рівня сироваткового IgA на 6,4 \%. Концентрація IgM та IgG мала тенденцію до зростання. У цієї категорії пацієнток ступінь імунних порушень не виходив за межі першого рівня, що не потребує імунокорекції. Таким чином, ПМЦ у жінок, хворих на ТБ легень, супроводжується зниженням функціональної здатності В-лімфоцитів, незважаючи на компенсаторне збільшення їх відносної кількості у перифрерійній крові.

\section{СПИСОК ЛІТЕРАТУРИ}

1. Концепція Державної програми «Репродуктивне здоров'я нації на 2006-2015 роки» / Кабінет Міністрів України. Розпорядження від 27 квітня 2006 р. № 244-р. м. Київ. - Нормативно-правові документи: Медичний індекс - акушерство та гінекологія. - 2006. - № 4. - С. 24-26.

2. Неконтрацептивные эфректы комбинированных оральных контрацептивов у женщин, больных туберкулезом / Р. М. Айдамирова, О. Г. Жученко, А. Е. Грабарник [и др.] // Туберкулез и болезни легких. - 2011. - № 4. - С. 19-20.

3. Антипкін Ю. Г. Репродуктивне здоров'я жінок як важлива складова покращення демографічної ситуації в Україні / Ю. Г. Антипкін // Журн. АМН України. - 2007. - Т. 13, № 3. - C. 476-485.

4. К вопросу о патологии иммунитета при туберкулезе легких / В. В. Новицкий, О. В. Воронкова, О. И. Уразова [и др.]// Патологическая фризиология и экспериментальная терапия. - 2008. - № 1. - С. 15-18.
Оцінка досліджуваних показників імуно-гормонального гомеостазу у жінок, хворих на ТБ, упродовж МЦ засвідчує, що системний імунітет $є$ нестійким, його ланки працюють у напруженому режимі, що слід враховувати при призначенні коригуючої гормональної терапії.

Висновок. У пацієнток репродуктивного віку, хворих на туберкульоз легень, фрормується набутий імунодефіцитний стан за клітинним типом зі зниженням відносної кількості Т-лімфоцитів, зростанням супресорного компонента імунної відповіді, що сприяє порушенням менструальної функції.

ПЕРСПЕКТИВИ ПОДАЛЬШИХ ДОСЛІДЖЕНЬ. У наступних дослідженнях планується вивчення рівня цитокінового профрілю при порушенні менструальної функції у жінок, хворих на туберкульоз.

5. Клічук Р. В. Порушення репродуктивного здоров'я у жінок, хворих на туберкульоз легень / Р. В. Клічук, С. П. Польова, А. М. Біньковська // Клінічна та експериментальна патологія. - 2011. - Т. Х, № 4 (38). - С.46-48.

6. Клічук Р. В. Чинники ризику розвитку туберкульозу ужінок репродуктивного віку / Р. В. Клічук, С. П. Польова // Одеський медичний журнал. - 2012. - № 1 (129). - С. 38-40.

7. Тодоріко Л. Д. Сучасні аспекти перебігу туберкульозу легень у жінок / Л. Д. Тодоріко // Мед. аспекты здоровья женщины. - 2015. - № 4 (90). - С. 56-61.

8. Чернушенко К. Ф. Імунологічні методи у діагностиці туберкульозу / К. Ф. Чернушенко // Лабораторна діагностика. - 2005. - № 2 (32). - C. 61-66.

9. Kothari A. Tuberculosis and pregnancy. Results of a study in a high prevalence area in London / A. Kothari, N. Mahadevan, J. Girling // Eur. J. Obstet. Gynecol. Reprod. Biol. - 2006. - Vol. 126, № 1. - P. 48-55. 